\title{
Proposal for a Semantic Hierarchy of Terminological Metaphors in Science and Technology
}

\author{
Georgina Cuadrado ${ }^{1} \&$ Pilar Durán ${ }^{2}$ \\ ${ }^{1}$ Universidad Politécnica de Madrid (Spain), Agronomy Engineering School, Spain \\ ${ }^{2}$ Universidad Politécnica de Madrid (Spain), Mining Engineering School, Spain \\ Correspondence: Georgina Cuadrado, Agronomy Engineering School, Universidad Politécnica de Madrid, Spain. \\ E-mail: georgina.cuadrado@upm.es
}

Received: April 30, 2013 Accepted: May 22, 2013 Online Published: July 17, 2013

doi:10.5539/ijel.v3n4p1 URL: http://dx.doi.org/10.5539/ijel.v3n4p1

\begin{abstract}
Cognitive linguistics is considered as one of the most appropriate approaches to the study of scientific and technical language formation and development, where metaphor is accepted to play an essential role. This paper, based on the Cognitive Theory of Metaphor, takes as the starting point the terminological metaphors established in the research project METACITEC (Note 1), which was developed with the purpose of unfolding constitutive metaphors and their function in the language of science and technology. After the analysis of metaphorical terms and using a mixed corpus from the fields of Agriculture, Geology, Mining, Metallurgy, and other related technical fields, this study presents a proposal for a hierarchy of the selected metaphors underlying the scientific conceptual system, based on the semantic distance found in the projection from the source domain to the target domain. We argue that this semantic distance can be considered as an important parameter to take into account in order to establish the metaphoricity of science and technology metaphorical terms. The findings contribute to expand on the CTM stance that metaphor is a matter of cognition by reviewing the abstract-concrete conceptual relationship between the target and source domains, and to determine the role of human creativity and imagination in the language of science and technology configuration.
\end{abstract}

Keywords: applied linguistics, cognitive linguistics, science and technology, conceptual metaphor, metaphorical hierarchy

\section{Introduction}

\subsection{The Role of Metaphor in the Creation of New Meaning in Science and Technology}

When new scientific or technical concepts arise, it is necessary to find specific terms to name them. However, a great deal of those technical terms is also part of more general everyday vocabulary. A frequent mechanism is to use existing words, which then take on new meanings that are metaphorically related to their old meanings. 'All forms of thought are creative in the sense that they produce new links, new configurations, and correspondingly, new meaning and novel conceptualization', affirms Fauconnier (1997, p. 149). Temmerman \& Campenhoudt (2011, p. 1) add that 'Renewed interest in both the dynamics of cognition and the creative potential of language has changed the perspectives on the creation of neologisms in special languages, on the monosemy versus polysemy debate, on the research concerning ambiguity, synonymy, metaphor, [....]'.

Studies in the rhetoric of science have frequently appeared in the last decades concerning the generative power of metaphor and highlighting the importance of metaphor as a constituent part of scientific discourse (Fahnestock, 1999; Boyd, 1993; Collins \& Gentner, 1995). Thus, cognitive theory of metaphor has been applied to the study of theory building in different special language fields (Salager-Meyer, 1990, in Medicine; White Hayes, 2004, in Economy; Roldán, 1999, in Civil Engineering; Úbeda, 2003, and Caballero, 2006, in Architecture; Cuadrado and Berge, 2007, in Quantum Physics; Siqueira, Souto de Oliveira, Hubert, Faé de Almeida \& Grangel, 2009, in Environmental Law; Cuadrado 2010, in Mechanical Engineering; Robisco, 2011, in Aeronautics, to mention a few). Today, evidence of the effectiveness of this approach to the study of metaphor use within different fields of science and technology continues to accumulate.

In a study conducted in 1993, Boyd established a link between metaphor and theoretical change and distinguished between two main functions of metaphor in science: exegetical and constitutive. This distinction is particularly 
relevant for our study, centred in lexical metaphors, which have a constitutive function. The exegetical or explanatory function of metaphor is used to explain scientific concepts, for example, by way of analogy. If we say 'the Colorado River is a sculptor that carves and chisels the Grand Canyon', the metaphorical expression 'is a sculptor that carves and chisels' is exegetical, whereas the metaphorical term 'canyon' is constitutive; i.e., it has become a geological term in itself. Exegetical metaphors are frequently present in popularised science and in the press; and this has given rise to abundant literature (Hanks, 2006; Ciapuscio, 2011). On the other hand, the constitutive function is present when metaphors become part of scientific thought, being an essential support for it in concept development; research publications from this point of view are much scarcer, especially within the realm of engineering.

Although the Cognitive Theory of Metaphor (CTM) has been applied to scientific language in several works and the function of metaphor has been clearly and satisfactorily determined (Boyd, 1993; Knudsen, 2003), there remains a need to conduct more thorough studies to identify the complex interactions within metaphorical terms' networks in the different fields of science and engineering (Steen, 2011). With this purpose, and based on the analysis of technical and sub-technical metaphorical terms in different scientific fields, we have developed a working database, which contains a cognitive semantic analysis of metaphorical terms and conceptual mappings in science and technology, from which the exemplifying data presented in this paper have been taken. Thus, the starting point of this analysis of scientific terms is the study of conventional, lexical, or dead metaphors. By lexical metaphors it is understood those that have entered into the lexicon univocally; that is, having one specific meaning linked to a specific scientific field. Although the force of the word may appear to be no longer active, we assume that those metaphors that have unconsciously been built into the language by long-established conventions are especially important for comprehending human mind, including understanding the mechanisms involved in word formation and scientific concept development.

In this paper, we will first consider the basic premises of cognitive theory that underpin our study, which do not respond to surface linguistic criteria, but to the underlying cognitive processes involved in the scientific conceptual system and the human mind's mental projections when creating new terms. Then, we will describe the methodology adopted, exemplified with some representative metaphors from four particular areas of engineering: Agriculture and Livestock Farming; Geology and Mineralogy; Mining; and Metallurgy, to narrow the scope of our paper in order to make it viable. By means of a specific corpus built for this purpose, we will include metaphorical terms developed along the years up to the most recent times. It is important to point out that the mechanisms analysed in word formation and concept development apply not only to traditional and fundamental branches of natural science or of old engineering fields such as mining, agronomy or forestry, but also to newer scientific and technical developments such as engineering materials, environmental sciences, genetics or nuclear physics.

Finally, we will discuss the most representative conceptual mappings and blending, and the technical and sub-technical terms involved. In this respect, Fauconnier $(1997$, p. 1) affirms that reasoning phenomena include 'conceptual projection, conceptual integration and blending, analogy, reference, and counterfactuals'; we will call on these reasoning activities when discussing the mappings between domains. Although we have come across abundant image metaphors and metonymic expressions, we have left them aside, as our primary interest is to determine the presence of organicist and humanizing metaphors to express concepts related to both animate and inanimate entities, that is, taking into account the ontological nature of the domains involved.

\subsection{Cognitive Linguistics Theory: Basic Preliminaries}

Cognitive Semantics provides a satisfactory model to explain how metaphorical terms are generated by the scientific community, accounting for the social influence of history, culture and even ideology. Its contribution develops from the following basic principles: (a) the Experiential Hypothesis (Johnson, 1987); (b) categorization and Prototype Theory (Rosh, 1977, 1978); and (c) the Theory of Metaphor (Lakoff and Johnson, 1987, 1999), revisited and opened to new developments (Steen, 1999, 2011).

(a) The Experiential Hypothesis (Johnson, 1987) is based on the assumption that our mind is inherently embodied; i.e., that meaning is grounded in and through our experiences, from sensory, motor and other neural systems (Lakoff and Johnson, 1999). As a result, a great part of our conceptual systems is either universal or widespread across languages and cultures. Thus, if we say that somebody is stone-cold or stone-dead, we are referring to our previous sensory experience of what a stone feels or looks like. There are many examples of scientific and technical lexicalized metaphors derived from basic sensory experiences. For instance, the term 'sustainability', referring to a basic physical experience, has recently turned into a source of conceptual metaphor: in environmental science, this term results from the experiential interaction with the world, deriving from the 
physical manipulation of objects. Nevertheless, we consider it important to add that terminological metaphors come, not only from human physical experience, but from abstract projections of human life experiences as well. In this sense, for example, when geological engineers use the term 'allied rock' they are projecting their experience of union to another person who gives help or support (allied), to 'rock entities' that have no hard and fast boundaries between them. Thus, allied rocks may be transformed into one another by an increase or decrease in the proportions of their constituent minerals.

(b) The Prototype theory and the principle of Categorization (Rosch, 1977, 1978), related to Wittgenstein's Family Resemblance (1953). Lakoff (1987, p. 6) highlights the importance of this phenomenon when he maintains that 'an understanding of how we categorise is central to any understanding of how we think and how we function, and therefore central to an understanding of what makes us human'. This view includes two important member categories: central and peripheral. This gives rise to the notion of gradability (Rosch, 1977, 1978). According to Evans and Green (2006, pp. 28-29) 'Human categories often appear to be fuzzy in nature, with some members of a category appearing to be more central and others more peripheral. Moreover, degree of centrality is often a function of the way we interact with a particular category at a given time'. When applied to metaphor, gradability refers to the degree of metaphoricity a metaphor has. By this we mean that the fewer semantic properties the source domain and the target domain share, the more metaphorical a metaphor is considered; and conversely, the more semantic properties the source domain and the target domain share, the less metaphorical a metaphor is.

(c) The Theory of Metaphor (Lakoff and Johnson, 1999; Lakoff, 1987) sustains that most abstract concepts and language expressions are largely metaphorical. This theory maintains that metaphor is a basic mechanism for understanding and categorising the world, as well as an important and decisive tool in human mental activities of inferring and reasoning. With respect to metaphor and categorization, Alexiev $(2004$, p. 193) explains that concept formation and our understanding and perception of the outer world proceeds neither from the largest possible entity to the smallest, nor from the smallest to the largest entity, but addresses the middle range of different classes of items, determined by the criteria which are considered appropriate in each case.

In this paper, we have adopted Lakoff and Johnson's traditional distinction (1980) of three major types of metaphors: conceptual metaphors, metaphorical expressions and image metaphors. Conceptual metaphors operate in our thought and can be defined as 'a cross-domain mapping in the conceptual system' (Lakoff, 1993, p. 203), whereas metaphorical expressions operate in our language and consist of particular words or phrases, which can express a conceptual metaphor. For instance, terms like 'parent rock' or 'mother rock' are metaphorical expressions included in the conceptual metaphor ROCK MEMBERS ARE FAMILY MEMBERS (Note 2).

Earlier versions of the Conceptual Metaphor Theory (CMT) were improved by extending their field of study from language and thought to social science and communication (Steen, 2008). Thus, Steen proposed a three-dimensional model of Metaphor and approached metaphor in discourse 'as a matter of usage events that require multiple mental representations by language users of aspects of language, thought, and communication' (2008, p. 232). The scope of this study, however, is reduced to language and thought; consequently, communicative aspects such as metaphor processing operations have been left aside. Mappings established in language and thought were needed at some point of usage in the history of the language, but later became irrelevant to the thought processes of the contemporary language user. The metaphorical meanings of certain words have become conventional, and in some cases even more frequently used than the non-metaphorical ones. According to Steen (2011, p. 55), this type of metaphors -the Official metaphorical models- may be described as:

Metaphors in thought that are officially instilled by formal education on the basis of explicit formulation in written or spoken texts as culturally sanctioned models of reality; these would include all accepted religious knowledge as well as scientific models of reality that are based on metaphor, such as the atom as a solar system, the mind as a computer, or the organization as a machine.

As we said above, CMT claims that metaphor is not primarily a question of language but of cognition. Thus, we will adhere to the basic principles of CMT, including the experiential hypothesis, taking 'experience' in its broadest sense, to analyse and interpret this piece of research data. Although the earlier versions of the CMT stand on solid theoretical grounds and can provide the basis for the framework of this study, we agree with Ruiz de Mendoza \& Perez Fernandez (2011, p. 183) that CMT 'needs to explore in more detail the notion of domain, especially the questions of domain types and degrees of abstraction in metaphorical operations. It also needs to explore metaphor by taking into account a number of complementary perspectives, among them, the ontological nature of the domains involved [...]'.

At a start, most classifications and analyses of metaphor were reduced to the nature of the source domain; for instance, personifications were classified as such whatever the target domain nature was. However, this study takes 
into account the ontological nature of both the source and the target domains, in accordance with CMT latest developments.

\section{Research Methodology}

The unfolding of lexical metaphors went through three steps followed by a fourth one to determine conceptual mappings:

(1) Hand searching of metaphorical terms in specialized dictionaries;

(2) Definition and decomposition of the terms into their semantic components. During this process, we found out that definitions themselves constituted an important source of further lexicalized metaphors.

(3) Contextualization of lexicalized constitutive metaphors using the electronic corpus of specialised written texts created for this purpose, which turned to be another source of lexicalized metaphors, and

(4) Analysis of the metaphorical terms included in the database to establish conceptual metaphors and mappings.

The metaphorical terms, and the cognitive metaphors and mappings included in the database were determined after a thorough analysis of the contextualised constitutive metaphors (Cuadrado, Duque \& Durán, 2007). The procedure has consisted in determining the systematic metaphor patterns, identifying and grouping topic domains and, finally, establishing groups of connected metaphors. Once a metaphorical term was classified into a specific conceptual metaphor, it was analysed in terms of its internal essential and non essential attributes, and then, its semantic features were decomposed.

\subsection{Methodology for the Identification Procedure of Lexicalized Metaphors}

With the purpose of avoiding individual subjective intuitions, we have guided ourselves by the following criteria proposed by Schmitt (2005) when identifying metaphor: (1) A word can be understood beyond the literal meaning in context of what is being said; (2) the literal meaning stems from an area of physical or cultural experience (the source area); (3) which is transferred to a second, often abstract, target area.

It is important to observe that the terminological metaphors analysed in this study constitute lexicalized metaphors. For this reason, the procedure followed by the research Group DISCYT (Note 3) was to consider as metaphorical any term that currently has or has had a well-defined contrast between the literal meaning and the scientific meaning. In lexicalized metaphors, metaphorical mappings are still active and generate a series of new metaphors, both lexicalized and non-lexicalized, as we have verified when contextualising metaphorical terms.

The decision to include a metaphorical term in our data base involved three steps:

1. Determine the literal meaning (or meanings) of the word in non-scientific language.

2. Determine the meaning in the area of science and technology analysed.

3. Contrast the specific scientific meaning and the basic meaning of the term in general language, and decide whether the scientific meaning provides more information than the basic meaning, and whether the term cannot be completely understood in a new scientific and technical context if only the general meaning is applied.

Then, an initial list was elaborated by searching for metaphorical terms in dictionaries, led by the 'informed intuition' of the different researchers in the DISCYT group. As Deignan (1999, p. 180) affirms, 'the researcher uses informed intuition to decide whether a particular citation of a word is metaphorical /... Intuition is also needed to decide whether a linguistic metaphor is a realisation of a particular conceptual metaphor'. According to Low (1999: 49), this is the commonest approach to metaphor identification. However, he adds that, in identifying metaphorical terms, there is a problem related to familiarity with specific words and that the researcher's knowledge of the topic area being studied may be considered to be a variable in metaphor identification. In our study, we have had the valuable opportunity of consulting with other academics specialised in the areas dealt with in this first stage of the study.

\subsection{The Specific Mixed Corpora}

\subsubsection{Referential Corpus Used in the Hand Searching Phase}

At a first stage, different technical dictionaries were surveyed in order to select all those terms in which metaphor is involved. A preliminary corpus was extracted from paper sources, as well as from electronic dictionaries on the web, mostly corpus-based; this corpus provided a preliminary list of metaphorical terms. 
Table 1. Features of referential corpus dictionaries

\begin{tabular}{|c|c|c|}
\hline Name & Features & Entries \\
\hline $\begin{array}{l}\text { McGraw-Hill Dictionary of Scientific } \\
\text { and Technical Terms }(2000)\end{array}$ & $\begin{array}{l}\text { Includes } 125.000 \text { definitions of } 104 \text { specific } \\
\text { scientific and technical fields }\end{array}$ & 110,000 \\
\hline $\begin{array}{l}\text { New Polytechnic Dictionary of the } \\
\text { English and Spanish Languages. } \\
\text { Volume I: English / Spanish (1998) }\end{array}$ & $\begin{array}{l}\text { All scientific and technical areas, including newer } \\
\text { ones such as microelectronics, telematics, genetic } \\
\text { engineering, biotechnology, etc }\end{array}$ & 275,000 \\
\hline $\begin{array}{l}\text { Nuevo Diccionario Politécnico de las } \\
\text { lenguas española e inglesa. } \\
\text { Volumen II: Español / Inglés (1998) }\end{array}$ & $\begin{array}{l}\text { All scientific and technical areas, including newer } \\
\text { ones such as microelectronics, telematics, genetic } \\
\text { engineering, biotechnology, etc }\end{array}$ & 300.000 \\
\hline $\begin{array}{l}\text { Oxford Dictionary of Earth Sciences. } \\
(1991 / 2003 / 2008)\end{array}$ & Earth science terms and definitions.- web linked. & 6,250 \\
\hline $\begin{array}{l}\text { Oxford Dictionary of Environment and } \\
\text { Conservation (2007) }\end{array}$ & $\begin{array}{l}\text { Economic, geographical, and political terms and } \\
\text { definitions }\end{array}$ & 8,000 \\
\hline $\begin{array}{l}\text { The Penguin Dictionary of Electronics } \\
\text { (1988) }\end{array}$ & $\begin{array}{l}\text { Areas: solid state devices and circuits, } \\
\text { semiconductors and semiconductor technology, } \\
\text { including associated fields such as physics and } \\
\text { computer technology. }\end{array}$ & 2,200 \\
\hline $\begin{array}{l}\text { Anmol's Dictionary of Geology (1987/ } \\
\text { 1998). }\end{array}$ & $\begin{array}{l}\text { Geology, mining and earth science terms and } \\
\text { definitions.- web linked. }\end{array}$ & 6,300 \\
\hline
\end{tabular}

Table 1 shows the specialised dictionaries surveyed, by alphabetical order, including terms in the areas of Agriculture and Livestock Farming, Geology and Mineralogy, Mining, and Metallurgy; other dictionaries were also consulted to translate and compare meaning, which are included in the bibliography section. Other monolingual English dictionaries consulted are The Oxford English Dictionary (1989) and Collins English Dictionary (2006), which have clarified the meaning of the terms studied and provided additional examples of scientific and technical terms.

\subsubsection{Textual Corpus for the Contextualization of Metaphorical Terms}

To analyse the semantic structure of the metaphorical terms in context, a specific untagged corpus of on-line scientific and technical journals written in English was created. This specific corpus made it possible to analyse the use of metaphorical terms in their context, and to identify those semi-technical lexicalized metaphors which were generated by other metaphors in real scientific communication.

This eight million word corpus was made up of two separate sub-corpora from 1999 to 2007, which we considered appropriate for our purposes. Following Wynne's criterion (2005, p. 18), 'not only [specialised corpora] are likely to contain fewer words in all, but it seems as if the characteristic vocabulary of the special area is prominently featured in the frequency lists, and therefore a much smaller corpus will be needed for typical studies than is needed for a general view of the language'. For our study, we required relevant updated research papers which would include the newest terminology, even those words which are not contained in most scientific and technical dictionaries. However, as not all metaphorical terms in the reference corpus were found in the textual corpus, we also used Electronic Journals and Free pages on the net.

Once created the digitalized corpus, we followed the standard procedure in analyses of this kind, called the KWIC concordance (Key Word in Context): all the citations of the term under study were found in the computer and then presented with a specific amount of context as lines of 200 characters with the metaphorical term (the node word) in the middle. This concordance was then further studied and analysed.

\subsection{Methodology for Establishing a Hierarchical Classification of Metaphorical Terms in Science and Technology}

We developed a hierarchy of the natural world categories from the simplest and most natural to the most complex and abstract ones. As metaphor itself, it is, to a certain extent, based on the researchers' 'informed intuition' of distance between categories, following the basic chain of beings. Matter (materiality, the external world) will be primarily divided into inorganic matter and organic matter, the latter including plants and animals. A higher level 
of complexity comprehends the human beings, both as living organisms and as intellectual beings, the latter including personal aspects and inter-social aspects; and, finally, the concepts derived from feelings, emotions, and moral and religious sentiments.

Thus, table 2 below proposes a hierarchy of metaphorical terms based on the distance between the categories of the source and the target domains, in which the source domains are the categories in the human world, and the target domains are categories in science and technology. The distance can be considered as a parameter to be taken into account when evaluating the level of metaphoricity of the terms involved.

Table 2. Distance between the categories of the source domain and the target domain

\begin{tabular}{l|ccccccc}
\hline Source & $\begin{array}{l}\text { Inorganic } \\
\text { (nature) }\end{array}$ & $\begin{array}{l}\text { Inorganic } \\
\text { (artificial) }\end{array}$ & Plants & $\begin{array}{c}\text { Animal \& } \\
\text { Human } \\
\text { physiology }\end{array}$ & $\begin{array}{c}\text { Human } \\
\text { development } \\
\text { \& reactive } \\
\text { behaviour }\end{array}$ & $\begin{array}{c}\text { Human } \\
\text { attitudes \& } \\
\text { social } \\
\text { behaviour }\end{array}$ & $\begin{array}{c}\text { Feelings and } \\
\text { beliefs } \\
\text { (Metaphysics) }\end{array}$ \\
\hline $\begin{array}{l}\text { Inorganic } \\
\text { (Nature) }\end{array}$ & 0 & 1 & 2 & 3 & 4 & 5 & 6 \\
\hline $\begin{array}{l}\text { Inorganic } \\
\text { (artificial) }\end{array}$ & 1 & 0 & 2 & 3 & 4 & 5 & 6 \\
\hline Plants & 2 & 2 & 0 & 2 & 4 & 5 & 6 \\
\hline Animals & 3 & 3 & 2 & 0 & 4 & 5 & 6 \\
\hline
\end{tabular}

The span between the source and the target domain categories shown in table 2 was ranked in a scale from 0 to 6 as follows:

(a) $0=$ no distance: the source and the target domain share the same category

(b) $1=$ low distance

(c) 2 = high distance

(d) 3, 4, 5, 6, = very high distance

\section{Results}

The hierarchy of the networks of metaphors we have discussed takes as starting point the most productive cognitive metaphors found in our metaphorical database, where metaphorical productivity is defined in relation to the number of metaphorical terms involved within the four scientific and technical fields analysed. That is, we examined the cognitive patterns that have generated the greatest number of metaphorical terms and mappings, established on the basis of empirical evidence, after isolating and analysing more than two thousand terminological metaphors. The most productive patterns are portrayed in table 3 .

\subsection{Metaphorical Patterns}

The hierarchy of the metaphorical mappings found covers a ranking ranging from the highest distance between source and target domain to the shortest distance between them, according to the categories they belong to (table 2). It is important to mention that metaphorical mapping can be considered from an epistemic or an ontological view point. Epistemic correspondences permit us to reason about a particular domain calling upon a previous knowledge normally used to reason about a different domain. Table 3 shows epistemic correspondences. As we can observe in all of our cases, the distance between the categories of the target domain and the source domain was found to be high or very high.

Although research is in progress, preliminary results show that in ontological correspondences, the distance between categories is usually low or medium. Thus, for instance, machinery and tools (inorganic/artificial) are usually conceptualized in terms of everyday human objects (inorganic/artificial). 
Table 3. Most productive conceptual mappings, metaphorical terms, categories, and semantic distance between categories

\begin{tabular}{|c|c|c|c|}
\hline Mental mappings & $\begin{array}{l}\text { Technical and sub-technical } \\
\text { metaphorical terms }\end{array}$ & $\begin{array}{l}\text { Categories in science } \\
\text { and technology } \rightarrow \\
\text { Categories in the } \\
\text { human world. }\end{array}$ & $\begin{array}{l}\text { Distance } \\
\text { between } \\
\text { categories }\end{array}$ \\
\hline $\begin{array}{l}\text { THE ENGINE } \\
\text { CARBURETOR IS THE } \\
\text { BODY RESPIRATORY } \\
\text { SYSTEM. }\end{array}$ & $\begin{array}{l}\text { 'Exhaust system', 'exhaust pipe', } \\
\text { 'exhaust manifold', 'air strangler', } \\
\text { 'choke', 'throttle'. }\end{array}$ & $\begin{array}{l}\text { Inorganic matter } \\
\text { (objects) } \\
\longrightarrow \\
\text { Animal Physiology }\end{array}$ & Very High \\
\hline $\begin{array}{l}\text { THE ENGINE’S FUEL } \\
\text { CONDUCTION } \\
\text { SYSTEM IS THE } \\
\text { DIGESTIVE SYSTEM }\end{array}$ & $\begin{array}{l}\text { 'Throat valve', 'feeder', 'feeding', } \\
\text { 'feed trough', 'feed drain tank', } \\
\text { 'feeding plunger', 'intake'. }\end{array}$ & $\begin{array}{l}\text { Inorganic matter } \\
\text { (objects) } \\
\underset{\text { Animal Physiology }}{\longrightarrow}\end{array}$ & Very High \\
\hline $\begin{array}{l}\text { A STRUCTURED } \\
\text { ORGANIZED SYSTEM } \\
\text { OF BEES IS THE } \\
\text { HUMAN SOCIAL } \\
\text { SYSTEM }\end{array}$ & $\begin{array}{l}\text { 'Queen', 'community', 'workers', } \\
\text { 'carpenter bee', 'colony', 'eusocial } \\
\text { bee', 'semisocial bee', 'solitary } \\
\text { bee'. }\end{array}$ & $\begin{array}{l}\text { Animals } \\
\longrightarrow \\
\text { Human society }\end{array}$ & Very high \\
\hline $\begin{array}{l}\text { A PLANT ILLNESS IS } \\
\text { AN ATTACK }\end{array}$ & $\begin{array}{l}\text { 'Attack', 'antagonism', } \\
\text { 'antagonist', 'plant defense'. }\end{array}$ & $\begin{array}{l}\text { Plants } \\
\longrightarrow \\
\text { Human society }\end{array}$ & Very high \\
\hline $\begin{array}{l}\text { A PLANT GROWING } \\
\text { INTO SOWN SOIL OR } \\
\text { OTHER NATIVE PLANT } \\
\text { COMMUNITIES IS } \\
\text { INVASION }\end{array}$ & $\begin{array}{l}\text { 'To invade', 'invasion', 'invader', } \\
\text { 'invasive competition', 'invasive } \\
\text { exotics', 'invasive alien species', } \\
\text { 'invaded ecosystem', } \\
\text { 'colonization', 'non-indigenous } \\
\text { plants', 'invasive plant species'. }\end{array}$ & $\begin{array}{l}\text { Plants } \\
\longrightarrow \\
\text { Human society }\end{array}$ & Very high \\
\hline $\begin{array}{l}\text { WINE FEATURES ARE } \\
\text { HUMAN CHARACTER. }\end{array}$ & $\begin{array}{l}\text { 'Character, 'elegant', 'dominant', } \\
\text { 'delicate', 'feminine', 'masculine', } \\
\text { 'vigorous'. }\end{array}$ & $\begin{array}{l}\text { Plants } \\
\underset{\text { Human character }}{\longrightarrow}\end{array}$ & Very high \\
\hline $\begin{array}{l}\text { A CLASS OF } \\
\text { MINERALS OR ROCKS } \\
\text { IS A FAMILY OF } \\
\text { ROCKS. }\end{array}$ & $\begin{array}{l}\text { 'To descend', 'descendant', } \\
\text { 'genealogy,' 'ancestor rock', } \\
\text { 'ancestral', 'daughter element', } \\
\text { 'parent rock', 'parent material', } \\
\text { 'parent element', 'mother rock', } \\
\text { 'twin crystal', 'family of rocks'. }\end{array}$ & $\begin{array}{l}\text { Inorganic matter (nature) } \\
\longrightarrow \\
\text { Human social system }\end{array}$ & Very high \\
\hline $\begin{array}{l}\text { ROCKS ARE SOCIAL } \\
\text { BEINGS }\end{array}$ & $\begin{array}{l}\text { 'Community', 'member', 'to host', } \\
\text { 'host rock', native mineral', } \\
\text { 'population', 'grouping', 'intruder', } \\
\text { 'intrusion', 'allied rock'. }\end{array}$ & $\begin{array}{l}\text { Inorganic matter (nature) } \\
\longrightarrow \\
\text { Human social system }\end{array}$ & Very high \\
\hline $\begin{array}{l}\text { ROCKS / SOILS } \\
\text { FEATURES ARE } \\
\text { LIVING ORGANISM'S } \\
\text { FEATURES }\end{array}$ & $\begin{array}{l}\text { 'Juvenile rock', 'rejuvenation', } \\
\text { 'ancient rock', 'immature soil', } \\
\text { 'mature soil', 'soil age', 'young } \\
\text { soil', 'old soil', 'dormant volcano', } \\
\text { 'quiescent volcano'. }\end{array}$ & $\begin{array}{l}\text { Inorganic matter } \\
\text { (nature) } \\
\longrightarrow \\
\text { Physiology }\end{array}$ & Very High \\
\hline $\begin{array}{l}\text { PARTS OF A } \\
\text { ROCK/MINERAL ARE }\end{array}$ & $\begin{array}{l}\text { 'Ore body', 'eye-structure', } \\
\text { 'amygdaloidal', 'blind hole', 'floor }\end{array}$ & $\begin{array}{l}\text { Inorganic matter } \\
\text { (nature) }\end{array}$ & Very High \\
\hline
\end{tabular}




\begin{tabular}{|c|c|c|c|}
\hline LIVING ORGANISMS & $\begin{array}{l}\text { limb', 'footwall', 'underlimb', } \\
\text { 'belly', 'tails', 'tailings', 'ore } \\
\text { barrenness', 'rock creeping'. }\end{array}$ & $\longrightarrow$ Animal Physiology & \\
\hline $\begin{array}{l}\text { IRON FEATURES IS } \\
\text { HUMAN CHARACTER }\end{array}$ & $\begin{array}{l}\text { 'Active iron', 'inactive iron', } \\
\text { 'passive iron', 'hungry iron', 'pure } \\
\text { iron', 'grown iron', 'dull iron'. }\end{array}$ & $\begin{array}{l}\text { Inorganic matter (nature) } \\
\longrightarrow \\
\text { Human character }\end{array}$ & Very high \\
\hline $\begin{array}{l}\text { STEEL FEATURES ARE } \\
\text { BODY FEATURES }\end{array}$ & $\begin{array}{l}\text { 'Strain-aging steel', 'strain-aged } \\
\text { steel', 'antifatigue steel', 'sound } \\
\text { steel', 'dead steel', 'killed steel', } \\
\text { 'unkilled steel', 'semikilled steel', } \\
\text { 'metal fatigue', 'blister steel'. }\end{array}$ & $\begin{array}{l}\text { Inorganic matter } \\
\underset{\text { Physiology }}{\longrightarrow}\end{array}$ & Very High \\
\hline $\begin{array}{l}\text { STEEL FEATURES IS } \\
\text { HUMAN CHARACTER }\end{array}$ & $\begin{array}{l}\text { 'Tough steel', 'mild steel', 'lively } \\
\text { steel', 'wild steel', 'tempered steel', } \\
\text { 'antifatigue steel', 'sound steel'. }\end{array}$ & $\begin{array}{l}\text { Inorganic matter } \\
\longrightarrow \\
\text { Human character }\end{array}$ & Very high \\
\hline $\begin{array}{l}\text { PARTS OF STEEL ARE } \\
\text { PARTS OF THE BODY. }\end{array}$ & $\begin{array}{l}\text { 'Hardfaced steel', 'skin hardened } \\
\text { steel', 'clad steel'. }\end{array}$ & $\begin{array}{l}\text { Inorganic matter } \\
\underset{\text { Physiology }}{\longrightarrow}\end{array}$ & Very High \\
\hline $\begin{array}{l}\text { MACHINE PARTS ARE } \\
\text { PARTS OF THE BODY. }\end{array}$ & $\begin{array}{l}\text { 'Catch nose', 'driving tongue', } \\
\text { 'finger', 'chute finger', 'teeth', } \\
\text { 'digger teeth', 'stub tooth', } \\
\text { 'coupling link', 'jaw coupler', } \\
\text { 'neck ring'. }\end{array}$ & $\begin{array}{l}\text { Inorganic matter } \\
\text { (Objects) } \\
\longrightarrow \\
\text { Animal Physiology }\end{array}$ & Very High \\
\hline $\begin{array}{l}\text { ROCK AND MINERAL } \\
\text { DEVELOPMENT IS } \\
\text { PLANT } \\
\text { DEVELOPMENT }\end{array}$ & $\begin{array}{l}\text { 'Exfoliation', 'exfoliate', } \\
\text { 'foliation', 'rock peeling', 'crop', } \\
\text { 'crop out', 'crop-end', 'cropping', } \\
\text { 'cropper', 'buried outcrop', } \\
\text { 'sheaf-like structure', 'sand grains'. }\end{array}$ & $\begin{array}{l}\text { Inorganic matter (nature) } \\
\underset{\text { Plants }}{\longrightarrow}\end{array}$ & High \\
\hline $\begin{array}{l}\text { METALLURGICAL } \\
\text { PROCESSES ARE } \\
\text { PLANT PROCESSES }\end{array}$ & $\begin{array}{l}\text { 'To sprout', 'sprout', 'vegetation', } \\
\text { 'refined grain', 'mottled grain'. }\end{array}$ & $\begin{array}{l}\text { Inorganic matter (nature) } \\
\longrightarrow \\
\text { Plants }\end{array}$ & High \\
\hline $\begin{array}{l}\text { WINE AGE IS A LIVING } \\
\text { ORGANISM AGE. }\end{array}$ & $\begin{array}{l}\text { 'Age', 'ageing', 'old', 'young', 'to } \\
\text { mature'. }\end{array}$ & $\begin{array}{l}\text { Plants } \\
\underset{\text { Physiology }}{\longrightarrow}\end{array}$ & High \\
\hline $\begin{array}{l}\text { PARTS OF A PLANT } \\
\text { ARE PARTS/ORGANS } \\
\text { OF THE BODY }\end{array}$ & $\begin{array}{l}\text { 'Eye', 'axil', 'heart', 'hair', 'rib', } \\
\text { 'tissues', 'pores', 'neck'. }\end{array}$ & $\begin{array}{l}\text { Plants } \\
\longrightarrow \\
\text { Animal Physiology }\end{array}$ & High \\
\hline $\begin{array}{l}\text { THE PLANT } \\
\text { CIRCULATORY } \\
\text { SYSTEM IS THE BODY } \\
\text { CIRCULATORY } \\
\text { SYSTEM. }\end{array}$ & $\begin{array}{l}\text { 'Vascular system', 'vascular } \\
\text { bundle', 'vascular tracheid', } \\
\text { 'veins', 'vessels', 'vessel element'. }\end{array}$ & $\begin{array}{l}\text { Plants } \\
\longrightarrow \\
\text { Animal Physiology }\end{array}$ & High \\
\hline
\end{tabular}

Dealing with metaphor in thought and language, White Hayes (2001, p. 48) argues that 'language is made by man for his needs, and, consequently, it's not surprising that language is characteristically anthropocentric'. In this sense, the conceptual metaphors presented above can be classified into the two metaphorical 'anthropocentric' patterns: the body pattern, including the body as a frame, the body as a container and the body as a living organism (the body functions); and the human being as a psychical entity, encompassing the human being as a social and as a metaphysical entity. 


\subsection{Discussion of Results}

In this section, we will discuss some examples of the hierarchy of terms shown in table 3, based on the semantic distance between categories developed in table 2, and examine a few of the cases illustrative of this hierarchy of metaphors from the highest to the lowest distance between categories.

\subsubsection{Examples of Very High Distance between the Categories of Source Domain and Target Domain}

The analysis of the lexical metaphors contained in table 3 shows that the metaphor of Physiology referred to objects and things can be found in all four areas presented in this study. As we can see, the highly productive conceptual metaphor underlying the concept 'BODY', can be subdivided into two metaphorical patterns:

(i) the body as a frame containing parts and organs ('eyes', 'hair', 'ribs', etc.), and

(ii) the body as a living organism, including maturing and ageing, as well as the body functions.

Another highly metaphorical pattern underlying the conceptual metaphors presented above is the humanizing pattern, which includes mappings related to:

(iii) the human being as a psychical entity,

(iv) the human being as a social entity.

(i) Metaphors related to Anatomy involve the parts of the body, as it is shown in the highly metaphorical following examples.

- In Geology, the terms 'ore body', 'eye structure', 'belly', 'tails', 'amygdaloidal', and 'floor limb' give an account for the mental mapping PARTS OF A ROCK ARE PARTS OF A LIVING BODY.

- In Mining work machinery, the terms 'catch nose', 'driving tongue', 'finger', 'chute finger', 'teeth', 'digger teeth', 'coupling link', 'jaw coupler' and 'neck ring' reveal the mental mapping MACHINE PARTS ARE PARTS OF A LIVING BODY.

This mapping includes terms referring to certain parts of a body but with particular functions which are not the typical body functions, but correspond to another mental space; this is the case, of 'catch nose', 'driving tongue', 'digger teeth' and 'jaw coupler'. These terms give evidence for the cognitive process of blending (Fauconnier, 1997), by which two input mental spaces (e.g. catch + nose) yield a new blend, ('the catch nose').

- In Metallurgy, steel is conceptualized as a living body that matures, ages and dies. The terms 'strain-aging steel', 'strain-aged steel', 'antifatigue steel', 'sound steel', 'dead steel', 'killed steel', 'unkilled steel', 'semikilled steel', give evidence for the mental mapping STEEL FEATURES ARE THE BODY FEATURES.

- The body respiratory system is present in the next example, taken from Agriculture in the area of farm machinery: THE ENGINE CARBURETOR IS THE BODY RESPIRATORY SYSTEM. The terms involved are: 'exhaust system', 'exhaust pipe', 'exhaust manifold', 'air strangler', 'choke', and 'throttle'.

In this case, we observe that in the engine's respiratory system the throttle is the valve that directly regulates the amount of air entering the engine, maintaining a relatively constant fuel/air ratio.

- In the field of Agriculture and farm machinery, the body's digestive system constitutes the frame for the mental mapping THE ENGINE'S FUEL CONDUCTION SYSTEM IS THE DIGESTIVE SYSTEM. The terms involved are 'throat valve', 'feeder', 'feeding plunger', 'intake', and 'feed drain tank'.

A further highly metaphorical pattern underlying the conceptual metaphors presented above is the humanizing pattern, which includes mappings related to the human being as a psychical entity, and as a social entity. This type of metaphorical pattern awards feelings and behaviour to entities and things.

(iii) Mappings related to the human being as a psychical entity. The mental mappings involved evidence that entities and things behave, meaning that they not only respond to stimuli but they do it intentionally, in a particular way, led by personal characteristics.

- An example taken from the field of Metallurgy refers to iron. The terms 'active iron', 'inactive iron', 'passive iron', 'hungry iron', 'pure iron', 'grown iron', 'dull iron', all refer to human character and feelings, hence they evidence the mental mapping IRON FEATURES ARE HUMAN CHARACTER.

Iron is generally defined as the 'commonest of all metallic elements (Fe)' used in various forms in combination with carbon element. Iron combines well with other elements - metals and non-metals. Hence, most of the human attitudes and attributes applied to iron found so far: 'active iron', 'inactive iron', 'pure iron', 'dull iron', and 'passive iron', are related in some way to its capacity to combine with other elements or to present itself on its own: pure iron'. As it is known, metals have no mental or moral qualities, so their properties are involuntary; for this 
reason, this type of conceptual metaphor may be considered to have a very high degree of metaphoricity.

- The case of steel defined as a 'strong, hard alloy of iron and carbon' used for arms, tools, machinery and vehicles, due to its enduring properties, also reveals the projection of the human being qualities as a psychical entity on to the metal: STEEL FEATURES ARE HUMAN CHARACTER. The human attributes applied to steel, found in our search, are 'tough steel', 'mild steel', 'lively steel', 'wild steel', 'tempered steel', 'antifatigue steel', and 'sound steel', all related to the quality of endurance and certain behavioural attitudes.

As we said above commenting on iron, steel is an inanimate entity whose properties cannot depend on mental or moral qualities. Thus, we can say that the conceptual metaphor IRON/ STEEL FEATURES IS HUMAN CHARACTER has a very high degree of metaphoricity, as it is the outcome of human reasoning phenomena, including conceptual projection, rather than a mere analogy between the source domain and the target domain. High metaphoricity implies the presence of man's cognitive elaboration, as Bruner (1957, p. 234) puts it 'The intelligent mind creates from experience generic coding systems that permit one to go beyond the data to new and possibly fruitful predictions'.

'Character' is defined as the 'mental or moral qualities that make one person, community or race different from others' (Oxford Advanced Dictionary of Current English); that is, the particular combination of qualities in a person that make him distinct from others. Human traits are generally grouped under the categories of attitudes, attributes, social endowments and skills. Applied to iron and steel, we have found several human attitudes and attributes but neither social endowments nor skills, except for the case of 'stainless steel families'.

- Another of the most outstanding examples of very high metaphoricity comes from the area of Oenology, this time including both personal attributes and social endowments. In WINE FEATURES ARE HUMAN CHARACTER we find a very rich source of terminological metaphors, which describe this drink with the main features of the human character: 'elegant', 'dominant', 'delicate', 'feminine', 'masculine', 'vigorous', and 'strong'.

(iv) The human being as a social entity involves the concepts of FAMILY and SOCIETY. In Metallurgy, there are 'stainless steel families'; in Geology, a CLASS OF MINERALS AND ROCKS IS A FAMILY OF ROCKS; bees and ants organize themselves as a society; and plants attack and invade other plants territories, just to mention a few of the most outstanding examples. Let us analyse some of these cases.

- The mapping ROCKS ARE SOCIAL ENTITIES includes the terms 'community', 'population', 'member', 'rock family', 'native mineral', 'grouping', 'to host', 'host rock', 'intruder', 'intrusion', and 'allied rocks', which call upon friendly human attitudes ('host') and non-friendly ones ('intruder').

- The conceptual metaphor taken from Agriculture A PLANT ILLNESS IS AN ATTACK, contains the terms 'attack', 'antagonism', 'antagonist', and 'plant defence', among others.

- Another mental mapping taken from Agriculture is A PLANT GROWING INTO SOWN SOIL IS AN INVASION, which includes the terms 'invader', 'invasion', and 'invasive competition'.

These two latter mappings touch on the metaphor of WAR, which is an extremely frequent case of metaphor based on human activity, not only in general language but also in science and technology.

- An example of the highest level (6) of distance was found in the field of Electronics, in the compounds 'ghost image' or 'ghost pulse', meaning 'an unwanted signal appearing on the screen of a radar indicator caused by echoes, with a basic repetition system differing from that of the desired signals'. 'Ghost' is also used in metallurgy to describe a flaw or defect.

In such contexts, the scientific term ' $g$ host', where the projection spiritual world $\rightarrow$ inorganic world is established, is highly metaphorical. A ghost, in general language, means a disembodied soul; especially the soul of a dead person believed to be an inhabitant of the unseen world. Its first known use dates from 11th century.

\subsubsection{Examples of High Distance between the Categories of Source Domain and Target Domain}

- In Agronomy, the metaphorical terms 'eye', 'axil', 'heart', 'hair', 'rib', 'tissues', 'pores', and 'neck' give evidence for the mental mapping PARTS OF A PLANT ARE PARTS/ORGANS OF THE BODY.

- A further example related to the body as a living organism is also found in Agriculture, related to plants: THE PLANT CIRCULATORY SYSTEM IS THE BODY CIRCULATORY SYSTEM. The terms 'vascular system', 'vascular bundle', 'vascular tracheid', 'veins', 'vessels', and 'vessel element' give evidence for the mapping.

- The organicist metaphor in the example taken from the field of Geology, ROCKS AND MINERALS ARE PLANTS, includes the terms 'exfoliation', 'exfoliate', 'foliation', 'crop', 'crop out', 'crop-end', 'cropping', 
'sand grains', and 'buried outcrop'.

3.2.3 Examples of Medium/Low Distance between the Categories of Source Domain and Target Domain

In table 3 we presented the most productive mental mappings found in our research, limited to the four fields selected for this paper. But there are many other terms with different degrees of distance that also form part of our database. The following examples illustrate the cases of lower distance.

Level 1, low distance:

- The term 'bed' involves a mapping from inorganic (human world) to inorganic (natural world). A bed is defined as 'a piece of furniture on which to sleep' or, in a wider sense, as 'any place in which a person or animal sleeps or rests'. In Earth Sciences, 'bed' means 'a layer of rock, especially sedimentary rock', or 'the bottom of a river, lake, or sea'. Both the source domain and the target domain are inorganic inanimate entities, one from the human world and the other from the natural world; that is why we allotted them a one point distance.

Level 0 , the source and the target domains share the same category:

- The term 'spoon' found in fishing activities establishes a mapping from the inorganic human world $\rightarrow$ to the inorganic human world, too. Spoon is defined as 'a utensil consisting of a small, shallow bowl on a handle, used in preparing, serving, or eating food'. In Fishing, it means 'a shiny, curved, metallic fishing lure'. In both cases, it is a shallow, generally metal utensil used for several purposes.

\section{Conclusions}

The present study on metaphorical terms in a specialised mixed corpus supports the hypothesis that metaphor is central to scientific language and thought, not only on an exegetical or explanatory basis, but also on a constitutive basis. This goes in line with previous Cognitive Theory of Metaphor studies, which claim that metaphor is primarily a matter of cognition.

Taking the analysis of the scientific lexicon including over twenty eight thousand terms as the starting point, this work develops some of the most productive mental mappings that correspond to conceptual metaphors underlying the language of science and technology. Then, it proposes a hierarchy of metaphorical terms based on the distance between the categories of the source and the target domains, in which the source domains are the categories in the human world, and the target domains are categories in science and technology. This distance, which was found to be very high is most of the cases analysed, can constitute a parameter to be taken into account when evaluating the level of metaphoricity of these terms. The recurrent presence of the metaphor related to human beings in these mappings shows that the language of science and technology, made by humans for their needs, is basically anthropocentric. The results not only show that most epistemic metaphors analysed are created from concepts which belong to very distant categories, but also suggest that in science and technology, different metaphorical terms may present different degrees of metaphoricity when measuring the distance between the source domain and the target domain. The examples of the mental mappings IRON/ STEEL FEATURES IS HUMAN CHARACTER, THE ENGINE CARBURETOR IS THE BODY RESPIRATORY SYSTEM, and THE PLANT CIRCULATORY SYSTEM IS THE BODY CIRCULATORY SYSTEM evidence the complex underlying humanizing metaphors applied to animate and inanimate entities such as metals, engines or plants. Not considering the cultural or pragmatic aspects of language and conceptualization of the world, but only the relationship between language and reality, most of the cognitive metaphors found can be classified as highly metaphorical.

This study evidences that most technical concepts share properties such as inanimate and inorganic, and are relatively concrete in nature. It also shows that the metaphors used to express them are frequently animate and organic; that is, the tendency found in the mappings established in our database goes from the concrete to the abstract. This finding is particularly interesting because it contradicts the directionality of metaphor in natural language where it shows a tendency to go from the more complex and abstract to the simpler and concrete, the target usually more abstract than the source. Therefore, this is a case of conceptual interactional phenomena that go in opposite direction from that of general language.

We hope this work contributes to support the view that metaphor is essential to scientific reasoning and that metaphorical terms are created not merely on a literal basis, but on a largely imaginative reasoning process. Consequently, the study points to a new line of research on the generation and role of constitutive metaphor in relation to the understanding of scientific and technical concepts and the construction of meaning and language in this field.

\section{References}

Alexiev, B. (2004). Towards an Experientialist Model of Terminological Metaphorisation. Terminology, 10(2), 
189-213. http://dx.doi.org/10.1075/term.10.2.03ale

Allaby, M. (1991/2003/2008). Oxford Dictionary of Earth Sciences. OUP.

Boyd, R. (1993). Metaphor and theory change: What is metaphor a metaphor for? In A. Ortony (Ed.), Metaphor and Thought (pp. 481-532). Cambridge: Cambridge University Press. http://dx.doi.org/10.1017/CBO9781139173865.023

Bruner, J. S. (1957). Going beyond the information given. New York, NY: Norton.

Caballero, M. R. (2006). Re-viewing Space: Figurative Language in Architects'Assessment of Built Space. Berlin: Mouton de Gruyter. http://dx.doi.org/10.1515/9783110893892

Cameron, L., \& Low, G. (Eds.). (1999). Researching and Applying Metaphor. Cambridge: Cambridge University Press. http://dx.doi.org/10.1017/CBO9781139524704

Chhatwal, M. (1998/2004). Anmol's Dictionary of Geology 1987/1998. Anmol Publications, New Delhi. Retrieved from http://www.merriam-webster.com/dictionary

Ciapuscio, G. (2011). De metáforas durmientes, endurecidas y nómadas: Un enfoque lingüístico de las metáforas en la comunicación de la ciencia. Arbor. Ciencia, Pensamiento y Cultura, 187, 89-98.

Collins, A., \& Gentner, D. (1995). How People Construct Mental Models. In D. Holland, \& N. Quinn (Eds.), Cultural Models in Language and Thought. Cambridge: Cambridge University Press.

Crocker, D. (1999). Dictionary of Aeronautical English. London: Peter Collin Publishing.

Cuadrado, G. (2010). Un sistema de engranajes es un sistema planetario: Análisis de la metáfora cognitiva y los modelos mentales en el campo de la ingeniería. In T. Bungarten (Ed.), Akten des IX. Internationaler Kongress Der Europäischen Gesellschaft Für Fachsprachen. Hamburg: Universität Hamburg.

Cuadrado, G., \& Berge, H. (2007). Aportaciones al estudio de la metáfora en la Física Cuántica a partir de textos en inglés y en español. Ibérica, 13, 85-108.

Cuadrado, G., Duque, M. M., \& Durán, P. (2007). META-CITEC. A cognitive semantic database of conceptual metaphor in Science and Technology. In M. Edwards (Ed.), Proceedings of the BAAL Annual Conference 2007 (pp. 21-24). London, UK: Scitsiugnil Press.

Deignan, A. (1999). Corpus-based research into metaphor. In L. Cameron, \& G. Low (Eds.), Researching and Applying Metaphor (pp. 177-199). Cambridge UK: Cambridge University Press. http://dx.doi.org/10.1017/CBO9781139524704.012

Evans, V., \& Green, M. (2006). Cognitive Linguistics. An Introduction. Edinburgh: Edinburgh University Press. http://dx.doi.org/10.1515/COG.2006.016

Fahnestock, J. (1999). Rhetorical Figures in Science. New York, NY: Oxford University Press.

Falk, M. J., \& Gibbs, R. J. (2012). Embodied motivations for metaphorical meanings. Cognitive Linguistics, 23(2), 251-272.

Fauconnier, G. (1997). Mappings in Thought and Language. Cambridge, UK: CUP. http://dx.doi.org/10.1017/CBO9781139174220

Hanks, P. (2006). Metaphoricity is gradable. In A. Stefanowitsch, \& S. T. Gries (Eds.), Corpus-based approaches to metaphor and metonymy (pp. 17-35).

Johnson, M. (1987). The Body in the Mind: The Bodily Basis of Meaning, Imagination and Reason. Chicago: University of Chicago Press.

Knudsen, S. (2003). Scientific metaphors going public. Journal of Pragmatics, 35, 1247-1263. http://dx.doi.org/10.1016/S0378-2166(02)00187-X

Lakoff, G. (1987). Women, Fire and Dangerous Things. What Categories Reveal about the Mind. Chicago: University of Chicago Press. http://dx.doi.org/10.7208/chicago/9780226471013.001.0001

Lakoff, G. (1993). The Contemporary Theory of Metaphor. In A. Ortony (Ed.), Metaphor and Thought (pp. 202-251). Cambridge, UK: Cambridge University Press. http://dx.doi.org/10.1017/CBO9781139173865.013

Lakoff, G., \& Johnson, M. (1980). Metaphors we Live By. Chicago: The University of Chicago Press.

Lakoff, G., \& Johnson, M. (1999). Philosophy in the Flesh. The Embodied Mind and its Challenge to Western Thought. New York, NY: Basic Books. 
McGraw-Hill Dictionary of Scientific and Technical Terms. (2000).

Robisco, M. M. (2011). Análisis Cognitivo de las preposiciones en torno al eje de verticalidad en el inglés para la aeronáutica. Madrid: Editorial Doppel.

Roldán, A. M. (1999). Applications of Cognitive Theory to interdisciplinary work in Languages for Specific Purposes. IBÉRICA, 1, 29-38.

Rosch, E. (1978). Principles of Categorization. In E. Rosch, \& B. B. Lloyd (Eds.), Cognition and Categorization (pp. 27-48). Hillsdale, NJ: Lawrence Erlbaum Associates.

Salager-Meyer, F. (1990). Metaphors in medical English prose: A comparative study with French and Spanish. English for Specific Purposes, 9, 145-159. http://dx.doi.org/10.1016/0889-4906(90)90004-V

Schmitt, R. (2005). Systematic Metaphor Analysis as a Method of Qualitative Research. The Qualitative Report, 10, 358-394.

Schön, D. A. (1993). Generative metaphor: A perspective on problem-setting in social policy. In A. Ortony (Ed.), Metaphor and thought (2nd ed., pp. 137-163). Cambridge, UK: Cambridge University Press. http://dx.doi.org/10.1017/CBO9781139173865.011

Siqueira, M., Souto de Oliveira, A. F., Hubert, D. D., Faé de Almeida, G., \& Grangel, L. M. (2009). Metaphor identification in a terminological dictionary. IBÉRICA, 17, 157-174.

Steen, G. J. (2008). The paradox of metaphor: Why we need a three-dimensional model of metaphor. Metaphor and Symbol, 23(4), 213-241. http://dx.doi.org/10.1080/10926480802426753

Steen, G. J. (2011). The contemporary theory of metaphor - now new and improved! Review of Cognitive Linguistics, 9(1), 26-64. http://dx.doi.org/10.1075/ml.9.1.03ste

Temmerman, R., \& Van Campenhoudt, M. (2011). The dynamics of terms in specialized communication: An interdisciplinary perspective. In R. Temmerman, \& M. Van Campenhoudt (Eds.), The dynamics of terms in specialized communication: An interdisciplinary perspective. Terminology, 17(1), 1-8.

The Oxford Dictionary of Environment and Conservation. (2007).

The Oxford English Dictionary (2nd ed., 20 vols.). (1989). Oxford: Clarendon Press.

The Penguin Dictionary of Electronics. (1988).

The Penguin Dictionary of Telecommunications. (1983).

The Telecommunications Illustrated Dictionary. (2002).

Úbeda, P. (2003). Metaphor at work: A study of metaphors used by European architects when talking about their projects. IBÉRICA, 5, 35-48.

White Hayes, M. (2001). Metaphor and Metonymy in Thought and Expression. In G. Aguado, \& P. Durán (Eds.), La investigación en Lenguas Aplicadas: Enfoque Multidisciplinar (pp. 47-64). Madrid: Universidad Politécnica de Madrid.

White Hayes, M. (2004). Turbulence and turmoil in the market or the language of a financial crisis. IBÉRICA, 7 , 71-86.

Wittgenstein, L. (1953). Philosophical Investigations. Oxford, UK: Basil Blackwell.

Wynne, M. (Ed.). (2005). Developing linguistic corpora: A guide to good practice. Oxford, UK: Oxbow Books.

\section{Notes}

Note 1. This terminological database and the glossary of conceptual mappings constitute a research project carried out by the research group DISCYT and financed by the regional government of Madrid and the Universidad Politécnica de Madrid (Spain). The project belongs to the IV PRICIT programme of Science and Society, which aimed at the globalisation of science. This database includes a dictionary providing the translation into Spanish and the definition of scientific and technical terms, with images when possible, as well as a glossary of the conceptual metaphors found.

Note 2. The cognitive metaphors or deep level cognitive mappings illustrating our point will appear in capital letters, while the metaphorical expressions are in italics and between inverted commas, according to conventional notations in cognitive linguistics. 
Note 3. The Universidad Politécnica de Madrid research group DISCYT 'Estudios cognitivos y sociopragmáticos del discurso científico y técnico' is made up of nine English teaching staff from the Schools of Architecture, Agriculture, Civil Engineering, Mining, Aeronautical and Telecommunications Engineering, and Physical Education and Sports Science.

\section{Copyrights}

Copyright for this article is retained by the author(s), with first publication rights granted to the journal.

This is an open-access article distributed under the terms and conditions of the Creative Commons Attribution license (http://creativecommons.org/licenses/by/3.0/). 